\title{
Linguistic Capital as Foreign Domination Structure in Tourism Domain: a Case Study in Seminyak Bali
}

\author{
Made Budiarsa $^{1}$ and Yohanes Kristianto ${ }^{2}$ \\ English Literature Departement, Faculty of Cultural Sciences, Udayana University \\ Denpasar Bali, Indonesia \\ made_budiarsa@yahoo.com \\ Travel Industry Study Program, Faculty of Tourism, Udayana University \\ Denpasar Bali, Indonesia \\ inselbali@yahoo.com
}

\begin{abstract}
Focus of this paper is the practice of using linguistic symbols in tourism. The locus is in Seminyak Bali tourism area. The purpose of this paper is to (1) identify the forms of linguistic symbols as capital practiced in tourism, (2) to pattern the linguistic dominance over people (tourists) and economy, and (3) to describe the legitimacy of linguistic dominance. This paper uses a transdisciplinary perspective, namely social studies, and linguistics to analyze the linguistic dominance in tourism. The research method used is a qualitative method. Research data are lingual symbols (words and vocabulary) is done by a survey, interview, and documentary study. Data were analyzed descriptively with the concept of symbolic capital and the duality of structure. Research data indicate that the existence of language symbols has shifted from local character to global character. Language symbols as a representation of foreign capital in the streets of Seminyak Bali as a phenomenon of foreign capital domination practice in the realm of tourism. The results found: (1) forms of linguistic capital (foreign investors), (2) forms of linguistic domination of people (tourists) and the economy (goods), and (3) the legitimacy of linguistic capital.
\end{abstract}

Index Terms - linguistic capital, dominance, tourism domain, structure, landscape

\section{INTRODUCTION}

Language is a cultural product and a cultural form that lives in a social practice that can not be separated from its social context. The practice of language is also a linguistic exchange which is the communication relationship between the sender and the recipient of the message. Linguistic exchanges in social practice bring about the economic exchange for producers (messengers) and consumers (message recipients). To that end, language can be a linguistic capital in the market (social context) where people can gain both material and symbolic benefits[1] (Bourdieu, 1999).

The context of tourism is a social practice among tourism service providers and tourists as producers and consumers. The language is not only a mere consumerproducer communication tool but deeper into symbolic capital to control consumers in the tourism business. The language as symbolic capital in tourism business is shown by the form a lingual form for naming tourism infrastructure. In Legian Kuta, as the research that has been done by Budiarsa, et al. (2015) found foreign naming dominance in some infrastructure supporting tourism activities, such as hotels, restaurants, bars, cafes, and some shops [2]. The dominance of foreign investors in the tourism business is also indicated by the naming of star hotels in Bali which correlates with room prices (Susanto et al., 2015) [3]. It shows that language as linguistic capital can be used by tourism business investors to dominate tourists. Domination appears not only dominance over people (tourists), but also economic dominance associated with capital owners and the economic dominance of tourists.

The above facts provide an overview of the language as linguistic capital (symbolic) used to dominate the tourist 
economy, which in turn also dominates politically towards tourists. Correspondingly, tourism becomes a linguistic market in which linguistic capital is conditioned by the follow-up of dominance in it. This research seeks to reveal foreign dominations based on the facts of language as a symbolic capital in the tourism business. This paper will reveal the forms of foreign domination associated with symbolic capital (linguistic) in the tourism business of Bali. Therefore, this paper aims to: (1) identify the forms of the dominance of linguistic capital in the tourism business, (2) analyze the structure of linguistic capital dominance to the economy (a locative), (3) analyze the structure of linguistic capital dominance to people (tourists).

\section{MethodS AND PROCEDURES}

This study uses a qualitative approach to explore (Verstehen), tracing, refining, and interpreting variables (linguistic/language capital) as a dominant structure in tourism practice. The phenomenon of language is naturally experienced in the context of its use and meaning in social interaction (Creswell, 1998; Sudaryanto, 2015) [4][5]. This research takes place in the tourist area of Seminyak, Bali with the focus of linguistic forms as linguistics in the tourism business. For that reason, the focus and locus of this research are related to linguistic science as the formal object and the reality of language as the material object of linguistic study. The object of this study is the reality of the forms of language in the entity as linguistic capital (naming infrastructure supporting tourism activities) such as hotels, restaurants, bars, cafes, tourist information, etc. Qualitative data in the form of words, sentences, kema, and images obtained by observation and interviews of tourism actors. While quantitative data in the form of numbers show the value of the size of the variables it represents (Sugiyono, 2004)[6]. Secondary data obtained from previous research and library study related problems to be studied (Arikunto, 2010)[7].

Data collection is done by observing the atmosphere or circumstances according to the focus of research to be researched and in-depth interview techniques by conducting a conversation directed at a particular problem and is a process of oral question and answer in which two or more people are dealing physically to the perpetrators of tourism selected purposively as informants. Furthermore, the data is done by documentation that is a record of events that have been passed in the form of writing, drawings, or monumental work of someone (Sugiyono, 2008; Arikunto, 2010; Sudaryanto, 2015)[8][9][10]. Analyzing the data is done by reducing by classifying, directing, removing unnecessary, and organizing the data in a way so that the form to the conclusions can be taken. The next stage is to present data by displaying narrative text and matrices, graphs, networks, and charts. The final stage concluded by reviewing field notes, review and exchange of ideas among colleagues (Miles and Huberman, 2007)[11].

\section{RESULTS}

The essence of language is the structure that governs language practice. Language as a structure becomes the rule for every language speaker. However, language speakers are not actors who are always subject to language rules (grammar). Speakers have a transformative capacity to change and use the structure by comfort when speaking. It means that the language structure regulates not only the speakers of the language but also the resource of language speakers to use the language according to the language practice in their daily life.

The structure of the language regulates not only into the language itself but also regulates outwardly, the reader, the listener, even the context of space and time. The result of linguistic capital research as a structure of foreign dominance in Seminyak's tourism area linguistic structure can be identified as (1) signification structure, symbol, mention, and discourse, (2) domination structure over people, (3) dominance structure of economy, and (4) the structure of legitimacy as justification of how, when and where the structure of the language is practiced. This study focuses on special cases in certain spacetime (Yin, 2013)[12]

3.1 Forms of Linguistic Capital

Bourdieu (1999) assumes that linguistics can be a viable capital in economic logic [13]. The results of linguistic data collection in the form of lingual (words) forms can identify investors in the tourism business in Seminyak, Bali. The result of the identification of lingual data is done through field observation on hotel nameplate, restaurant, bar, and other business units. The results of observations confirmed to the perpetrators of tourism around the business unit under study. The forms of linguistic capital as a symbol of the investors in Seminyak area can be distinguished as follows.

\subsubsection{Foreign Capital}

The result of observation and interview with tourism actors in Seminyak area shows the dominance of foreign businessman who runs his business in Seminyak area. This foreign investor can be identified as an Asian, European, and American financier. Seminyak area seemed to grow rapidly after the tragedy of the bombing of Legian.

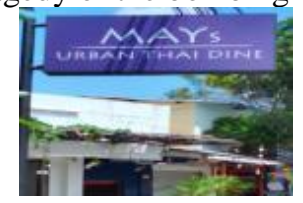

Fig. 1 Asian Capital

Figure 1 Urban Thai Dine restaurant is a business unit owned by Thai financiers.

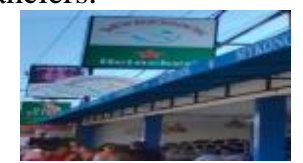

Fig. 2 European Capital

Figure 2 is a restaurant Mykonos as a symbol of Russian businessmen. 


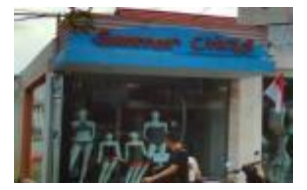

Fig. 3 American Capital

While figure 3, bistro Summer Chicks as a symbol of American businessmen.

\subsubsection{Local Bali and Non-Local Capital}

The results of the observation and interviews indicate there are only a few local businessmen from Bali and outside Bali who do business in the area of Seminyak. It is revealed by the names of business units that indicate local investors.

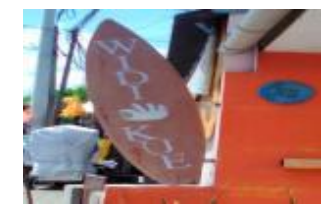

Fig. 4 Balinese Capital

Figure 4 is a Widi outlet as a marker structure of a local Bali businessman.

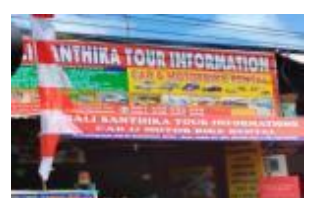

Fig. 5 Balinese Capital

Similarly, figure 5 , the Bali Santhika Tour, is a tourism service business unit that has a Balinese local business marking structure.

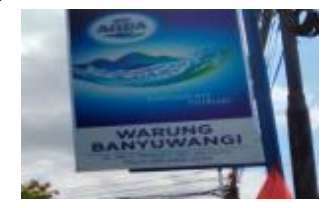

Fig. 6 Non-Local Capital

Meanwhile, figure 6 is Warung Banyuwangi, of course, the structure of the marking of the businessman can be known easily, that is from Banyuwangi (but outside Bali).

\subsubsection{Transnational Capital}

The results of the study found that businessmen who use transnational tagging structures. The transnational businessman is a businessman who conducts business by way of cooperation of foreign businessmen with local Bali or outside Bali. It is shown by the following data.

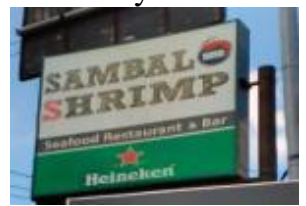

Fig. 7 Bali \& Holland

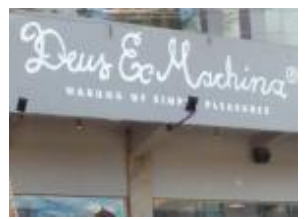

Fig. 8 Bali \& Italy

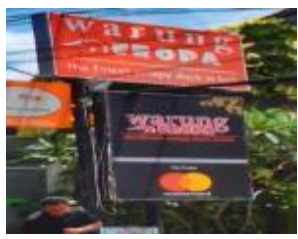

Fig. 9 Bali \& France

Figure 7 is Sambal Shrimp restaurant. Explicitly, the name of this restaurant is quite ambiguous, who the owner is. The research finds that the owner of this restaurant is a Dutchman who works with the local Balinese. Similar to Sambal Shrimp restaurant, figure 8 is an Italian restaurant packed with local menu offerings. It is marked by the slogan Warung of Simply Pleasure. This restaurant is owned by an Italian and a local Balinese person. Similarly, figure 9 is a European Café which is conceptualized as a local restaurant (warung), but offers European menus. The restaurant is owned by Frenchmen and local Balinese people.

3.2 Dominance of Linguistic Capital

The naming of business units in the Seminyak tourist area could establish a business landscape for investors who will do business in the region. The language structure in the lingual form can dominate the business position performed by foreign investors in competing with local investors. Foreign financiers can open their market segment with foreign capital to become familiar with tourists. It can be realized by way of structuring the symbol or marker of the origin of tourists who will become its market segment.

3.2.1 Foreign Domination

The results of the study identify the foreign investors were dominating business in the area of Seminyak is a businessman from Australia, France, Italy, Russia, and Japan. Linguistic capital in the form of foreign naming was able to master a particular market segment. Linguistic dominance became one of the strategies to seize the tourist market. It means that linguistic capital can be used to dominate people, i.e., tourists and at the same time economy (money). The following is presented data of linguistic dominance in Seminyak area.

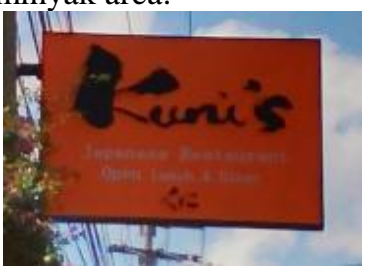

Fig. 10 Japanese Dominance

Figure 10 is a Japanese restaurant that certainly has a segment of Japanese tourists.

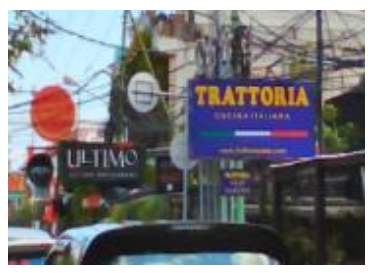

Fig. 11 Italian Dominance 
The same thing is also shown in figure 11, the Italian restaurant that shows the dominance of tourists from Italy.

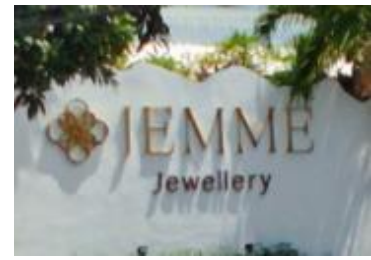

Fig. 12 French Dominance

Likewise, figure 12 , Jemme jewelry store, certainly explains the structure of dominance against French tourists who visit the tourist area of Seminyak.

\subsubsection{Transnational Domination}

The results also found transnational dominance. Businesspeople have both transnational business concepts and strategies. That is, business people want to dominate all segments of tourists both domestic and foreign. It is indicated by naming lingual naming that has transnational significance. Below are presented transnational dominance data.

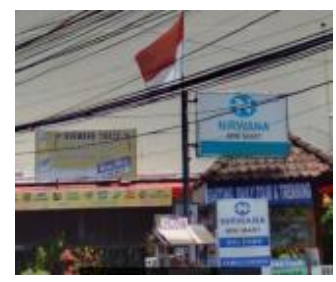

Fig. 13 Nirvana Minimart

Figure 13 is a minimart, tourist services agency, and lodging is a transnational business unit. Both domestic and foreign tourists can be dominated by business units owned by Australians and local Bali.

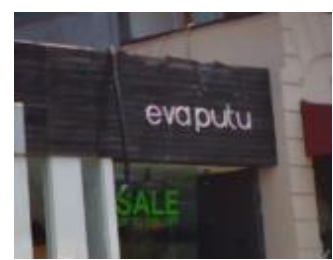

Fig. 14 Boutique Eva Putu

Figure 14, Eva Putu Boutique is owned by German and local businessmen of Bali. The boutique can open the domestic and foreign tourists market segment.

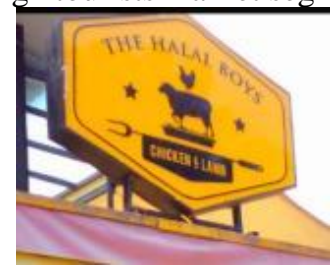

Fig. 15 Kedai Halal Boys

Meanwhile, figure 15 Halal Boys Store is a business unit owned by Arabs and local people. This shop can attract domestic and foreign tourists, especially Muslim tourists.

3.3 Legitimacy of Linguistic Capital

Legitimacy about the justification of something can or may be done. The naming of a business unit as a marker structure is certainly practiced by actors (businessmen) with certain rules. Business bureaucracy, of course, businessmen have passed the strict permission stage. It is legitimized by the issuance of business licenses and other documents. However, behind the business unit naming practices can form a foreign landscape in an area. It is evident, with so many foreign naming, the Seminyak tourist area has a quite foreign landscape when compared to tourist areas that have not been touched by foreign naming. The legitimacy of the use of foreign symbols or markers will need to be reviewed and given strict rules. Thus the local identity of Seminyak is not uprooted by the practice of foreign capital in the region.

\section{CONCLUSION}

Based on the results of research and discussion, it can be concluded as follows: (1) The forms of linguistic capital can identify businessmen in the Seminyak area, divided into foreign investors, local investors, outside Bali investors, and transnational investors; (2) The forms of linguistic dominance identify two forms of dominance for both tourists and money. These two dominations are foreign domination and transnational domination;(3) the Legitimacy of linguistic capital is done by the businessman only based on the motive or awareness of cognition to dominate the tourist segment.

\section{ACKNOWLEDGMENT}

The authors would like to thank the ministry of research and technology for higher education and research institution and community service of Udayana University who have provided Research Grant 2017.

\section{REFERENCES}

[1] Bourdieu, P. 1999. Language Symbolic and Power, in Jaworsky dan Coupland (ed), The Discourse Reader, 1999, p. 480

[2] Budiarsa, et.al, 2015. Linguaculture as Bali Tourism Identity. Research Report. Research Group. Udayana University

[3] Susanto, et al. 2015. Paradox of Hotel Brand Names in Bali: Divergence between Naming Trends and Consumer perception. Downloaded on $1^{\text {st }}$ of February 2017 available on: https://www.researchgate.net/publication/283720373

[4] Creswell, John W.1998, Qualitative Inquiry, and Research Design, Choosing. Among Five Traditions. California: Sage Publication

[5] Sudaryanto. 2015. Methods and Miscellaneous Language Analysis Techniques. Introduction to Linguistic Research. Yogyakarta: Sanata Dharma University Publisher

[6] Sugiyono. 2006. Qualitative-Quantitative Research Methods and R \& D. Bandung: Alfabeta

[7] Arikunto, Suharsimi, 2006. Research Procedure: A Practice Approach, Edition. Revision, Jakarta: PT. Rineka Cipta.

[8] Sugiyono. 2006. Qualitative- Quantitative Research Methods and $R \& D$. Bandung: Alfabeta

[9] Arikunto, Suharsimi, 2006. Research Procedure: A Practice Approach, Edition. Revision. Jakarta: PT. Rineka Cipta,

[10] Sudaryanto. 2015. Methods and Miscellaneous Language Analysis Techniques. Introduction to Linguistic Research. Yogyakarta: Sanata Dharma University Publisher

[11] Miles, M.B., dan Huberman, A.M. 1994. Qualitative data Analysis. Thousand Oaks, CA: Sage

[12] Yin, Robert K. 2013. Case Study Design \& Methods. Jakarta: PT. Raja Grafindo Persada

[13] Bourdieu, P. 1999. Languange Symbolic and Power, in Jaworsky dan Coupland (ed), The Discourse Reader, 1999, p. 480 